\title{
NOTA EN MEMORIA DE EUGENIO BULYGIN
}

\author{
María CRISTINA Redondo ${ }^{a, b}$ \\ https://orcid.org/0000-0002-3247-0977 \\ criredon@hotmail.com \\ ${ }^{a}$ Universidad de Génova, Génova, Italia \\ ${ }^{b}$ Consejo Nacional de Investigaciones Científicas y Técnicas, Argentina
}

Es difícil resumir en pocas palabras los múltiples motivos por los que recordaré siempre a Eugenio y por los que, más allá de mi experiencia en particular, creo que su huella será indeleble en la teoría jurídica. La relevancia de su legado es enorme. De ella dan cuenta la gran repercusión internacional de su obra y la gran cantidad de trabajos que no solo la comentan y profundizan, sino que articulan construcciones teóricas novedosas basadas en ella. Un legado que, aún oponiéndose a las corrientes de moda, está destinado perdurar como todo producto de excelencia.

Desde mi perspectiva, el recuerdo de Eugenio estará siempre ligado a la fortuna de haber formado parte, a partir de los años 80, de un privilegiado grupo de jóvenes que, impactados por sus ideas y completamente seducidos por su personalidad, gravitó en torno a él, aprendiendo el oficio a través de un incesante, y casi obsesivo, estudio de Normative Systems, su obra mayor, escrita con Carlos Alchourrón (Alchourrón \& Bulygin, 1971).

La buena fortuna y el privilegio fueron grandes, por una parte, porque no es posible exagerar la relevancia de Normative Systems, que constituye un ejemplo inigualable de aplicación de la filosofía analítica a problemas centrales de la teoría jurídica, y que nos proyectó internacionalmente con una carta de presentación de indiscutible prestigio. Pero, a la vez, porque la inicial atracción, basada en una justificada admiración intelectual, gracias al carácter de Eugenio, se convirtió en una relación de afecto y amistad pródiga de consecuencias beneficiosas.

Eugenio fue para mi un maestro. Una persona frente a la cual inicialmente se asume, en modo espontáneo, una actitud de respeto reverencial típica de la sujeción de autoridad paterna. Actitud que con el transcurrir del tiempo, casi inevitablemente, se transforma en una distancia crítica que nos permite finalmente volver, con mayor autonomía -y en mi caso con profunda convicción- habiendo tomado conciencia del inmenso valor de sus enseñanzas. En ese recorrido personal Eugenio 
fue siempre determinante. Varias decisiones vitales se debieron a sus consejos y estímulos. De hecho, fue en gran medida su impulso el que resolvió mi traslado de Córdoba a Buenos Aires y de Buenos Aires a Barcelona, para seguir estudiando. Y fueron sus seminarios los primeros en los que participé recién llegada a cada una de estas ciudades. De igual forma, son también varias las ocasiones en las que su proverbial intervención "imparcial" fue crucial para encarrilar mi suerte de la mejor manera. En todo caso, con su índole distinguida, jovial, abierta, intelectualmente vigorosa, lograba transformar lo que a mi parecer era una senda ardua y compleja en algo sencillo y liviano. Siempre tendré presente la generosidad de su trato en esos años decisivos y la calurosa hospitalidad con la que en cada ocasión posible me acogieron, tanto él como Elvira, su mujer.

La sola cercanía de Eugenio era saludable y predisponía al optimismo. Una persona radiante y afable que contagiaba su perspectiva positiva y a la que, contrariamente a lo que uno podría imaginar, una historia de vida signada por pasos difíciles y dolorosos parecía haberle inoculado una fuerte dosis de buen humor. Quienquiera que haya tenido contacto con él conoce las célebres sentencias con las que con elegante ironía decía verdades a veces incómodas, su disposición a la carcajada franca, su capacidad de disfrutar, en general, ya sea de un razonamiento sofisticado, de una iglesia románica, un verso, o una buena comida.

En la filosofía del derecho argentina, Eugenio es también testimonio, y sobre todo artífice, de muchos momentos saludables y que predisponen al optimismo. Así como en el destino individual de muchos de los que estudiaron con él, sus cualidades y acciones tuvieron una influencia capital en la generación de un ambiente intelectual de excepción que dio lugar a espacios como SADAF, seminarios como el que él llevó adelante por más de cincuenta años en la UBA, o Jornadas internacionales como las de Vaquerías en Córdoba. Estos espacios han siempre congregado a los mejores estudiosos de la materia y han contribuido decisivamente a proyectar el método de la filosofía analítica en la reflexión sobre el derecho y a dar su impronta a nuevos investigadores. En este sentido, la deuda de la teoría jurídica con Eugenio Bulygin es inconmensurable.

Habrá que habituarse a su ausencia. Afortunadamente, la vastedad de su herencia nos mantendrá en conexión permanente. Debiendo acostumbrarme a la idea, en este momento me vuelven a la mente incontables imágenes que me representan al hombre lúcido y delicado que fue en planos muy distintos. Si no fuese por su natural habilidad para conjugarlos, parecería mentira que puedan reunirse en la misma persona. A 
prueba de ello, y como alguna vez dijera Ernesto Garzón Valdés (1998), entre las variadas virtudes de Eugenio cabe subrayar que en la preparación de su vodka o su borschtsch era capaz de invertir la misma meticulosa atención que invertía en elaborar sus mejores papers. En latitudes tan distantes como Buenos Aires, Santa Catalina o San Petersburgo, celebro los momentos exquisitos que disfruté con Eugenio, conversando con él, paseando y escuchando su evocación de viejos tiempos, sus comentarios políticamente incorrectos, sus recomendaciones literarias. Fue un honor, y me conforta saber que la muerte es totalmente impotente frente a ellos.

\section{Bibliografía}

Alchourrón, C., \& Bulygin, E. (1971). Normative Systems. Springer.

Garzón Valdés, E. (1998). Appunti sul carattere e la personalità di Eugenio Bulygin. En P. Comanducci \& R. Guastini, Analisi e diritto 1997: Ricerche di giurisprudenza analítica (pp. 11-17.). Giappichelli.

Recibido el 30 de julio de 2021; aceptado el 3 de agosto de 2021. 